\title{
Should the Scope of Historical Citations on Cancer be Broadened?
}

\section{Wilson IB Onuigbo}

\author{
Department of Pathology, Medical Foundation and Clinic, 8 Nsukka Lane, Enugu 400001, Nigeria
}

Corresponding author: Wilson IB Onuigbo, Department of Pathology, Medical Foundation and Clinic, 8 Nsukka Lane, Enugu 400001, Nigeria, Tel: 2348037208680; E-mail: wilson.onuigbo@gmail.com

Received: 11 June 2016; Accepted: 21 July 2016; Published: 25 July 2016

Citation: Onuigbo WB. Should the Scope of Historical Citations on Cancer be Broadened? Arch Can Res. 2016, 4: 3.

\section{Abstract}

Citations on my 3 historical articles, which appeared between 1965 and 2010 in the top ranking Cancer Research, were used to show both positive and negative attitudes towards the $\mathbf{2 1}$ historical articles that, as a Third World scientist, I had published on this very important subject. From the analysis, it is hypothesized that scientific information should be cited critically so as to promote international investigations. In this context, this should apply whether they bear on history or on the current quest for the target therapy of cancer.

Keywords: Cancer; Blood; Lymph; Metastasis; History; Citations; Target therapy

\section{Introduction}

As many as 21 historical papers were published personally between 1958 and 2005. The first appeared in Cancer Research [1] and the others in chronological order [2-21]. All of them exemplify my contributions in the special field of the history of cancer metastasis. How, it may be asked, have American scientists cited them in Cancer Research, which is a high ranking USA based Journal?

\section{Positive Citations}

Journal of this prominence was utilized in 1965 by Vincent Triolo [22] to lay the 19th century foundations of cancer research. Incidentally, he took the trouble to draw particular attention to my papers in an Addendum as follows:

This article is offered (a) as a vehicle to the older literature in oncology, and (b) as a general survey of earlier trends in cancer research. Such limited dimensions do not permit the incorporation of critical evaluations and expanded discussions. This is a task for historically oriented professionals in clinical and experimental medicine.

It has not been possible to go beyond the rudiments of patho-physiologic concepts of metastases. This topic has been developed in several articles by Dr. Wilson I. B. Onuigbo (An Historical Criticism of Tumor Metastases, J. Hist. Med., 13
529-531, 1958; Lung Cancer in the Nineteenth Century, Med. Hist., 3: 69-77, 1959; Patterns of Metastases in Lung Cancer, A Review, Can. Res., 21: 1077-1085, 1961; Historical Trends in Cancer Surgery, Med. Hist., 6: 154-161, 1962; and The Paradox of Virehow's Views on Cancer Metastases, Bull. Hist. Med., 36: 444-449, 1962.

1962 turns out to be a noteworthy year because, by then, I had been publishing for only five years! Therefore, it is surprising that, Triolo [22] paid the above detailed attention to my embryonic historical papers.

Papers of historical interest, which were published in Cancer Research, included the one by Michael Shimkin [23]. In his own contribution, he went out of his way to cite two of my papers 1 and 4 in a list of 31 papers that he had recommended to those who wish to start to write in this field. Moreover, he added that I had "contributed valuable historical essays on several more specialized topics in cancer".

\section{Non Citations}

Cancer review of 2010 vintage by Talmadge and Fidler [24] was slanted as "history of pioneering observations" and as "historical perspective." However, although they included 236 references, yet no mention was made of any of my papers. Incidentally, out of these numerous references, the earliest was dated 1829, while the remaining four others appeared in only $1858,1864,1882$, and 1889 . Surely, these are in great contrast with the personal review 1, which I published concerning blood-borne metastasis in Cancer Research. Incidentally, it focused on 108 articles written from 1712 to 1900.

\section{Discussion}

Work, which is weighty, should have world-wide dimensions. Thus, when Eugene Garfield [25], the guru of scientific information, delivered the 1982 Annual Magnus Pyke Foundation Lecture, he said that "Most scientists in the West are not aware of research going on in Peru, Ghana, Singapore, or other countries collectively called the Third World." As he continued, "The representation of Third World research in international scientific journals is a neglected aspect of the New Information Order debate. How many research articles from Third World countries are published in journals from the 
developed countries? And what impact does Third World research have on the international scientific community?"

Community which consists of world class scientists should merit commensurate communications. In this context, let us go back to Eugene Garfield [26]. As he asked, "How can Third World Science be boosted?" Note how he answered thus: "Unfortunately, there is too little concern in the wider scientific community and in governmental agencies of the developed nations about the day-to-day problems confronting scientists in the Third World. Aside from neglect, there is prejudice as well."

Well stated, I think. Indeed, as he also posited [27], "Despite many problems, researchers in the developing nations manage to produce a significant portion of the world's scientific output. Imagine what these scientists could contribute to the global community if their difficulties could be reduced." Accordingly, I would hypothesize that one way of increasing the image of Third World scientists is for their work to be cited more often! In other words, as a matter of public policy, empathetic editors in developed countries should, as it were, even bend over backwards to accommodate their manuscripts!

Manuscripts should, as I see them, be submitted beyond one's own country. For instance, my historical papers were published in USA $[1,2,10,12,14,18-20]$, UK $[3,4,7,8,15]$, Switzerland [9-11], Denmark [4], India [9], Poland [13], The Netherlands [16], Italy [17], and New Zealand [21]. Clearly, USA predominated. Accordingly, I can conclude by suggesting that one's citation will be enriched by publishing in USA! However, one must carefully aspire to excel by following an acknowledged general principle [28], namely, "These citations have to be complete, correct and structured, so that all who want to work in the same field can easily find the cited papers."

Papers, in conclusion, should be composed by Third World scientists in such a way that they would not only write but also become citable. In this context, my recent researches have focused on the target therapy of cancer [29-32]. In all probability, when they come to fruition, Third World science would be seen to have been beneficial to all.

All papers of this type, it must be concluded, present personal perspectives. In other words, the experiences of any other writer remain to be reviewed by him or her. Certainly, it remains for others to communicate their own experiences so as to enrich the world's literature!

\section{References}

1. Onuigbo WB (1970) A history of hematogenous metastasis. Cancer Research 30: 2821-2826.

2. Onuigbo WB (1958) A historical criticism of tumor metastasis. Journal of the History of Medicine 13: 529-531.

3. Onuigbo WB (1960) History and the parasternal lymph-glands. Lancet I: 1249-1250.

4. Onuigbo WB (1962) Historical trends in cancer surgery. Medical History 6: 154-161.
Onuigbo WB (1963) The age-old dictum on the spread of tumours. Centaurus 8: 263-268.

6. Onuigbo WB (1963) A history of the cell theory of cancer metastasis. Gesnerus 20: 90-95.

7. Onuigbo WB (1964) Thomas Hodgkin (1798-1866) on cancer cell carriage. Medical History 11: 406-411.

8. Onuigbo WB (1970) Joseph Coats (1846-1899) of Glasgow and the theory of cancer metastasis. Scottish Medical Journal 15: 281-284.

9. Onuigbo WB (1970) Historical errors in neuroblastoma literature. Indian Journal of the History of Medicine 15: 20-22.

10. Onuigbo WB (1971) False firsts in cancer literature. Oncology 25 : 163-167.

11. Onuigbo WB (1972) Historical data on the dynamics of lymphatic metastases. Oncology 26: 505-514

12. Onuigbo WB (1975) Recognition and treatment of pathologic fractures in the 19th century. Surgery 77: 553-556.

13. Onuigbo WB (1975) The origins of the soil theory of cancer metastasis. Materia Medica Polona 7: 254-255.

14. Onuigbo WB (1976) Concepts of cancerous pathologic fractures in the 19th century. New York State Journal of Medicine 76: 771-772.

15. Onuigbo WB (1976) Secondary skin cancer in 19th century Britain. British Journal of Dermatology 94: 457-463.

16. Onuigbo WB (1984) Historical notes on cancer in married couples. Netherland's Journal of Surgery 36: 112-115.

17. Onuigbo WB (1984) Metastases in the abdominal wall after needle punctures: historical study. Italian Journal of Gastroenterology 16: 309.

18. Onuigbo WB (1985) Spontaneous rupture of hepatoma: historical perspectives. Southern Medical Journal 78: 1335-1336.

19. Onuigbo WB (1986) The Paget cell. Mistaken for a parasite a century ago. American Journal of Dermatopathology 8: 520-521.

20. Onuigbo WB (2005) Early descriptions of Krukenberg tumors. Journal of the American College of Surgeons 200: 111-112.

21. Onuigbo WB (2005) History of Medicine: Early description of cancer to cancer metastasis in 1848. New Zealand Medical Journal $118: 1210$.

22. Triolo VA (1965) Nineteeth century foundations of cancer research. Advances in tumor pathology, nomenclature, and the theories of oncologenesis. Cancer Research 25: 75-106.

23. Shimkin MB (1974) History of cancer research: A starter reading list and guide, Cancer Research 34: 1519-1520.

24. Talmadge JE, Fidler IJ (2010) AACR Centennial Series: The biology of cancer metastasis: historical perspective. Cancer Research 70: 5649-5669.

25. Garfield E (1983) Mapping science in the third world. Science and Public Policy 10: 112-127.

26. Garfield E (1987) How to boost third world science. The Scientist 1: 9.

27. Garfield E (1988) Supporting scientist-colleagues in the Third World is in our own best interest. Current Contents 16: 3 .

28. Kohler CO (1987) Analysis of citations in Four MIE proceedings. Medical Informatics 12: 53-61. 
29. Onuigbo WB (2013) Nature's necrosis factor when associated with erythrocytes may not only explain the surprises in lung cancer metastasis but also suggest target therapy. Medical Hypotheses 80: 698-700.

30. Onuigbo WB (2014) The scientific significance of the thoracic duct in cancer cell carriage: A review. Single Cell Biology 2: 104.
31. Onuigbo WB (2014) Anomalous lung cancer carriage: A historical review with present prospects. International Journal of Surgery 12: 734-736.

32. Onuigbo WB (2015) Can the hypothesized "Erythrocyte Associated Necrosis Factor" be applied to the prevention of metastasis? Journal of Cancer Prevention and Current Research. 